\title{
Altered immune response to insulin in newly diagnosed compared to insulin-treated diabetic patients and healthy control subjects
}

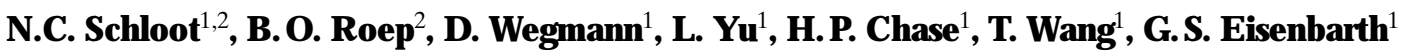 \\ ${ }^{1}$ Barbara Davis Center for Childhood Diabetes, University of Colorado, Denver, Colorado, USA \\ ${ }^{2}$ University Hospital Leiden, Department of Immunohematology and Bloodbank, Leiden, The Netherlands
}

Summary Insulin-dependent diabetes mellitus (IDDM) is the result of a T-cell mediated autoimmune beta-cell destruction,which is accompanied by autoantibodies. We analysed the cellular and humoral immune response to insulin and insulin peptides in patients with recent-onset IDDM, IDDM patients treated with insulin, non-diabetic first degree relatives and unrelated control subjects. There were no differences in T-cell reactivity to whole insulin or insulin peptides in general between age-matched groups of IDDM patients, relatives or healthy control subjects. In contrast to investigations in NOD mice, no immunodominant or disease-specific insulin peptide could be identified. Surprisingly, a positive correlation of T-cell responses to insulin with age was noted $(p<0.005)$. This resulted in an inverse relation of insulin autoantibodies (IAA) and insulin reactive $\mathrm{T}$ cells $(p<0.001)$ together with the well-described negative correlation of IAA with age. Interestingly, insulin-treated patients differed from age-matched recent-onset IDDM patients: first, simultaneous immune recognition of insulin with T-cells and IAA was only seen in patients treated for 6 months with insulin; second, insulin-treated patients rarely responded to whole insulin; third, they displayed less determinant spreading, and finally, recognition of multiple insulin peptides was not accompanied by crossreactivity to whole insulin. These distinct observations in insulin-treated IDDM patients, together with the inverse correlation between humoral and cellular responses to insulin, may result from activation or modulation of different T-cell subsets, and may be of relevance to insulin therapy trials, in which selective activation of non-destructive T-cell subsets may be a key to successful intervention. [Diabetologia (1997) 40: 564-572]

Keywords Insulin, autoantibodies, autoreactivity, Tlymphocytes, insulin-dependent diabetes mellitus.
Insulin-dependent diabetes mellitus (IDDM) is the result of a genetically associated autoimmune mediated process in which the insulin-producing pancreatic beta-cells are thought to be destroyed by autoreactive $\mathrm{T}$ cells $[1,2]$. The disease process is

Received: 11 November 1996 and in revised form: 14 January 1997

Corresponding author: Dr. N. Schloot, University Hospital Leiden, Department of Immunohematolgy and Bloodbank, Albinusdreef 2, NL-2333 AA Leiden, The Netherlands A bbreviations: IDDM, Insulin-dependent diabetes mellitus; GAD, glutamic acid decarboxylase; IAA, insulin autoantibodies; ICA, islet cell antibodies; PBMC, peripheral blood mononuclear cells; SI, Stimulation Index; IL, Interleukin. accompanied by autoreactive $\mathrm{T}$ cells and autoantibodies to various islet antigens. Many IDDM patients develop humoral immune responses to insulin $[3,4]$, islet cells [5], tyrosine phosphatase homologue islet cell antibody ((ICA)512/islet cell antigen (IA)-2, 37 K) [6-9] and glutamic acid decarboxylase (GAD) 65 [10-12]. Even though autoantibodies may not be directly involved in the destructive process, $60 \%$ of new-onset diabetic patients are positive for insulin autoantibodies (IAA) compared to only $0.5 \%$ of healthy control subjects [2]. The involvement of T cells in the pathogenesis has been implicated by insulitis [13], the recurrence of insulitis and diabetes after pancreas transplantation [14] and the transfer of diabetes with non-T-cell-depleted bone marrow transplants 
[15]. The nature of the islet antigen recognized by diabetogenic $T$ cells is unknown although $T$ cells of diabetic patients have been shown to react to various antigens such as insulin, insulin secretory granules, 38 $\mathrm{kDa}$ granule membrane proteins, RINm5F insulinoma membranes, fetal pig proislets, human islets and GAD [16-22]. However, the relation of such responses with the autoimmune-mediated beta-cell destruction process in IDDM is still an open question.

Even though the primary target antigen may not be known, in NOD mice pathogenic T cells have been shown to respond to various "antigens" including islets [23], beta-cell granules [24], GAD [25] and insulin [26], with a high frequency of insulin reactive $T$ cells at the site of insulitis [27]. Furthermore, treatment of prediabetic NOD mice with insulin (oral, subcutaneous, intranasal) [28-30] or GAD (intravenous, intrathymic, intranasal) [31-33], delays, or even prevents the onset of IDDM.

In a pilot trial in humans, administration of low dose subcutaneous and intravenous insulin to a small group of individuals at risk appears to delay or prevent diabetes [34]. The mechanism responsible for the protective effect of insulin therapy might involve immunomodulation, beta-cell rest or down regulation of beta-cell expressed autoantigens [35, 36]. Currently the Diabetes Prevention Trial is evaluating the preventive effect of such therapy on a large scale.

Insulin reactive $T$ cells from diabetic patients treated with animal insulin, and healthy control subjects have been cloned and shown to be MHC class II restricted $[16,37,38]$. The degree of T-cell reactivity to human insulin and insulin peptides has not been firmly established. In previous studies, primary cultures with peripheral blood lymphocytes showed a moderately higher insulin response of $\mathrm{T}$ cells in diabetic subjects [16] and prediabetic subjects [22] compared with first degree relatives and healthy control subjects, whereas others reported similar responses in IDDM patients and healthy control subjects [9, 39].

In the present study, we extended the analysis of peripheral blood $\mathrm{T}$ cells to investigate the recognition of insulin and linear insulin peptides in combination with insulin autoantibodies. To study the effect of exogenous insulin administration on T-cell responses, IDDM patients treated with human insulin for 6 and 12 months, in addition to newly diagnosed patients, healthy first degree relatives and unrelated age-matched healthy control subjects were investigated.

\section{Subjects and methods}

Probands. Informed consent was obtained from all subjects after the nature of the procedure was explained. We tested 22 children with newly diagnosed IDDM from Denver, Colorado, within 3 weeks after initiation of insulin therapy (Table 1). Additionally, we tested age-matched diabetic patients who had
Table 1. Number, gender and age of investigated IDDM patients, first degree relatives and control subjects

\begin{tabular}{|c|c|c|c|c|}
\hline \multirow[t]{2}{*}{ Group } & \multicolumn{2}{|c|}{ Gender } & \multicolumn{2}{|c|}{ Age [years] } \\
\hline & $\mathrm{n}$ & $\begin{array}{l}\text { male/ } \\
\text { female }\end{array}$ & mean & range \\
\hline Recent-onset IDDM & 22 & $11 / 11$ & 11.1 & $5.4-20.4$ \\
\hline 6 months IDDM & 11 & $6 / 5$ & 11.8 & $5.7-17.0$ \\
\hline 12 months IDDM & 12 & $8 / 4$ & 11.6 & $6.7-15.4$ \\
\hline $\begin{array}{l}\text { First degree relatives } \\
\text { at low risk }\end{array}$ & 21 & $12 / 9$ & 25.9 & $8.4-45.1$ \\
\hline $\begin{array}{l}\text { First degree relatives } \\
\text { at high risk }\end{array}$ & 21 & $12 / 9$ & 21.8 & $7.5-43.3$ \\
\hline $\begin{array}{l}\text { Unrelated young } \\
\text { control subjects }\end{array}$ & 19 & $4 / 15$ & 15.15 & $5.3-18.7$ \\
\hline $\begin{array}{l}\text { Unrelated adult } \\
\text { control subjects }\end{array}$ & 16 & $11 / 5$ & 31.25 & $21.4-46.8$ \\
\hline
\end{tabular}

manifest diabetes for 6 months and for 12 months and were all treated with human insulin. Healthy unrelated control subjects were tested for comparison and were defined as young control subjects if they were below 21 years of age (as were all diabetic patients tested) and as adult control subjects if they were above the age of 21 years.

Furthermore, we investigated first degree relatives of diabetic patients with at least two islet antibodies (IAA, GAD65, ICA), who were considered to be relatives at increased risk [40] and from first degree relatives with less than two antibodies (low risk relatives). Since the latter two groups consisted mainly of adults, we included adult unrelated healthy control subjects without any history of diabetes (Table 1). For testing we required $35 \mathrm{ml}$ peripheral blood drawn by venipuncture. The blood was used for investigation of lymphocyte autoreactivity, autoantibodies and HLA typing.

D etermination of autoantibodies. Insulin autoantibodies (IAA) were determined by a competitive radioimmunoassay as described previously. IAA titres $42 \mathrm{nU} / \mathrm{ml}$ and above were considered positive [8]. GAD65 autoantibodies and ICA were determined as described previously [8, 41]. ICA titres 20JDF and more and GAD65 autoantibodies above 0.032 (index of the 99th percentile of the normal range), were considered positive.

Determination of HLA. HLA-DQA1 determined by PCR based techniques using the AmpliType TM HLA DQalpha Forensic DNA Analysis kit (Perkin Elmer, Branchburg, N.J., USA) according to the manufacturer's instructions. HLA DQB1 was determined as described previously [42].

A ntigens. Recombinant human insulin (Sigma, St. Louis, Mo., USA) thawed from frozen $\left(-20^{\circ} \mathrm{C}\right)$ aliquots was tested at three different concentrations $(10,30,100 \mu \mathrm{g} / \mathrm{ml}$ respectively $16.7 \mu \mathrm{mol} / \mathrm{l})$ in the lymphocyte stimulation assays. A panel of synthetic peptides (Molecular Resource Center, National Jewish Center, Denver, Col., USA) based on the primary structure of murine insulin was tested at 5,15 and $50 \mu \mathrm{g} / \mathrm{ml}(26.3 \mu \mathrm{mol} / \mathrm{l})$. The amino acid sequence of insulin is highly conserved between species [43]. The peptides A2 (CTSICSLYQLENYCN) and B2 (SHLVEALYLVCGERG) are identical between human and murine insulin, whereas murine peptide A1 (GIVDQCCTSICSLYQ) and B1 (FVKQHLVGSHLVEAL) differ by a single amino acid and peptide B3 (YLVCGERGFFYTPMS) by two 


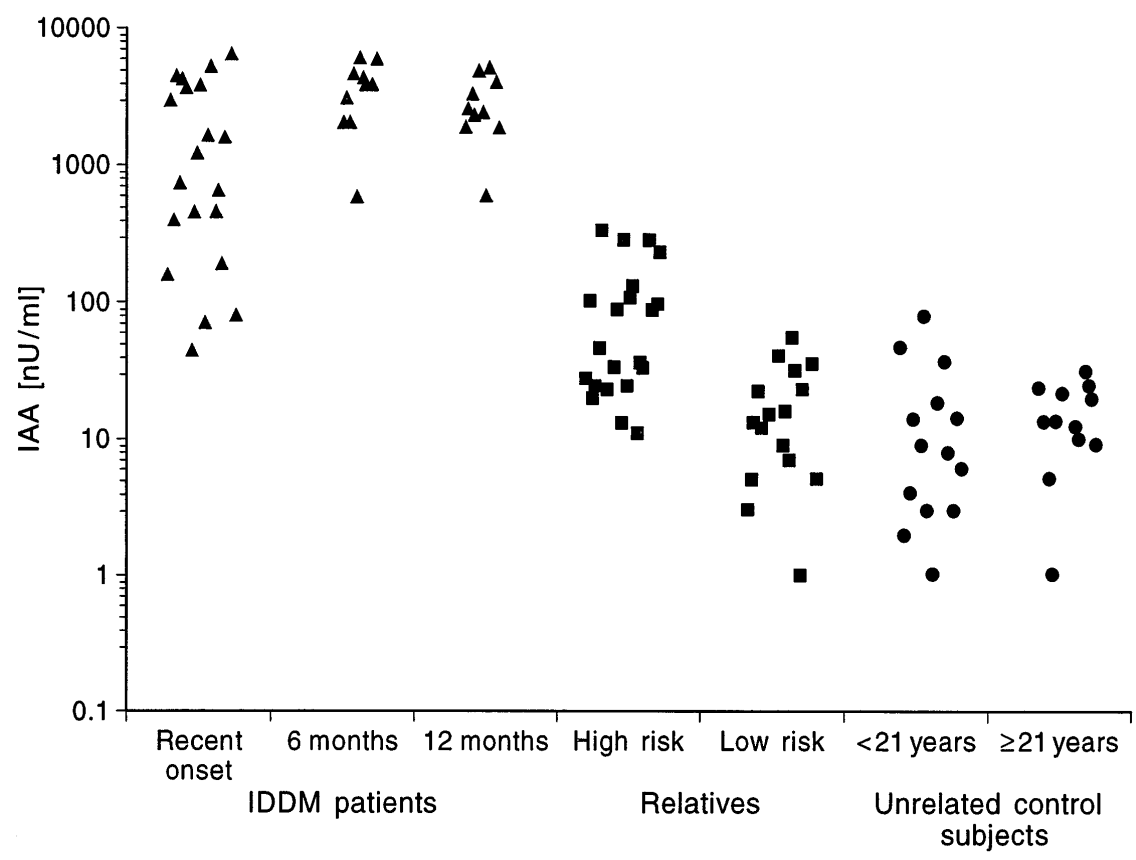

Fig. 1. Insulin autoantibody (IAA) titres of IDDM patients, first degree relatives and healthy control subjects. IAA levels of one IDDM patient treated for insulin for 6 months were so low, that they do not fit on the presented scale

terminal amino acids from human insulin (underlined amino acids are conservatively substituted, bold amino acids are nonconservatively substituted). Tetanus toxoid (Wyeth Labs, Pearl River, N. Y., USA) was dialysed and tested at a concentration of Limes Flocculation unit $/ \mathrm{ml}$.

Lymphocyte stimulation assay. The T-cell proliferation assay was performed as described previously with minor modifications using autologous serum [44]. In brief, 150000 freshly isolated peripheral blood mononuclear cells (PBMCs) were cultured in round bottomed 96-well plates for 6 days at $37^{\circ} \mathrm{C}$, $5 \% \mathrm{CO}_{2}$ in $150 \mu \mathrm{l}$ Iscove's modified Dulbecco's medium (Gibco BRL, Gaithersburg, Md., USA) containing 10\% autologous, normoglycaemic serum. Autologous serum was chosen to keep background proliferation low and to keep the in vitro experiments as close as possible to the situation in vivo. The PBMCs were incubated in triplicate wells in the presence of either human insulin, insulin peptides, tetanus toxoid, interleukin-2 (10\% Lymphocult T; Biotest, $\boldsymbol{\Delta}$, Germany) or in medium alone.

After 5 days $10 \mu$ l Hank's Balanced Salt Solution (Gibco) containing $0.5 \mu \mathrm{Ci}(=37 \mathrm{kBq})\left[{ }^{3} \mathrm{H}\right]$ thymidine (NEN, Dupont, Boston, Mass., USA) was added per well and the incubation was continued for $18 \mathrm{~h}$. Cultures were harvested and $\left[{ }^{3} \mathrm{H}\right]$ thymidine incorporation was measured by liquid scintillation counting. The results of lymphocyte proliferation are expressed as Stimulation Indices using the medians of a triplicate (cpm in the presence of antigen divided by cpm in the absence of stimulus [medium]). At a stimulation index of at least 3, which was considered positive, antigen-specific T-cell responses were significantly higher (Student's t-test) than the medium value.

\section{Statistical analysis}

Magnitude of T-cell proliferation of the different groups was compared using Mann Whitney U or Wilcoxon rank sum test. The frequencies of positive T-cell responses were compared using Fisher's exact test. The relation of age, T-cell proliferation and antibody responsiveness was determined by Rank Spearman correlation. Statistical analysis was performed with Graph Pad Instat using Graph Pad computer software for IBM.

\section{Results}

Insulin autoantibodies. All 42 diabetic patients except one who had diabetes for 6 months were positive for IAA (Fig. 1). We detected low titre IAA in 2 of 19 $(11 \%)$ young control subjects and in none of the 16 adult control subjects. In the group of first degree relatives, 12 of $42(29 \%)$ were positive for IAA, 11 of whom also had GAD antibodies and/or ICA antibodies and therefore were defined "at high risk".

ProliferativeT-cell responseto insulin. Freshly isolated PBMCs of diabetic subjects, first degree relatives of patients with IDDM and unrelated healthy control subjects, were cultured in $10 \%$ autologous serum with insulin at three different concentrations. Only experiments with PBMCs proliferating to interleukin (IL)-2 were included in the analysis. The groups did not differ in T-cell responsiveness to IL-2 or tetanus antigen [45]. The range of stimulation indices with tetanus toxoid was 10-15 times higher than the responses to insulin or insulin peptides and reached similar levels as in previous studies $[9,44,46]$. T-cell responses to tetanus toxoid did not correlate with insulin autoantibodies, T-cell responses to insulin, or age.

The insulin concentration giving maximal T-cell response to insulin varied, but $\mathrm{T}$-cell responses to 


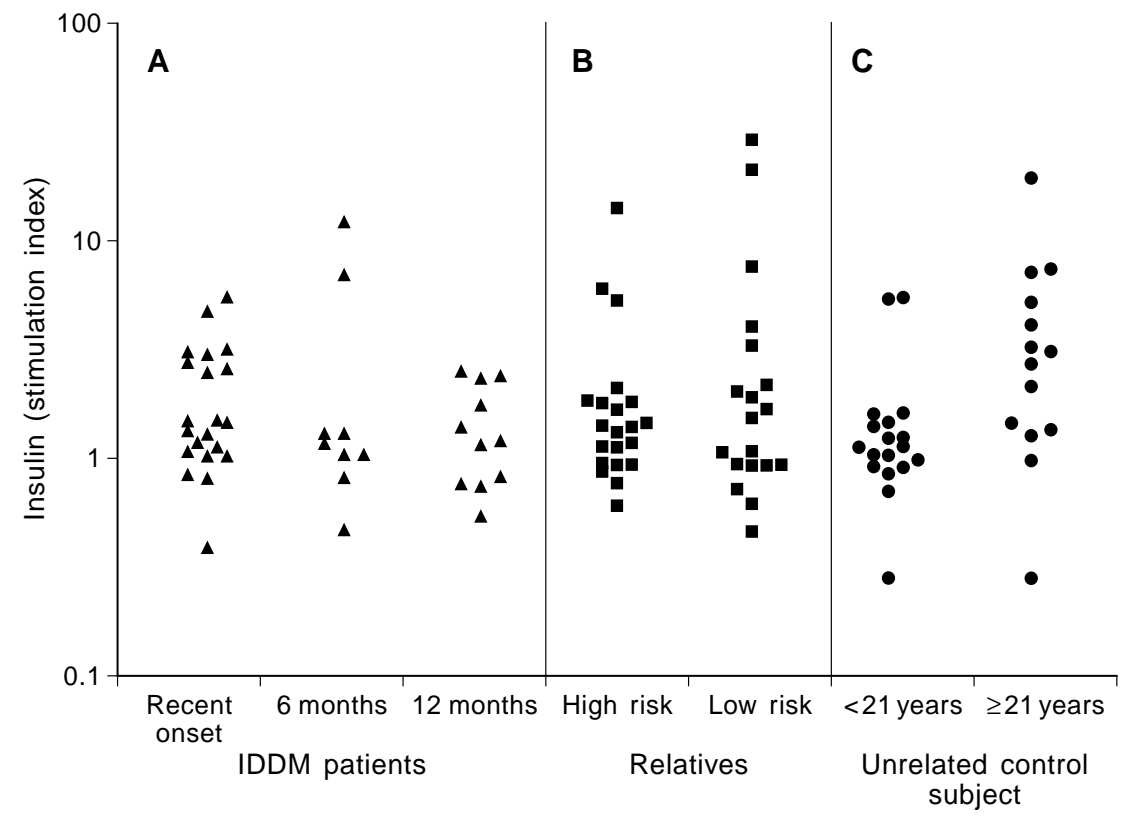

Fig. 2A - C. T-cell proliferation (stimulation index) to human insulin $(100 \mu \mathrm{g} / \mathrm{ml})$ of the investigated groups. A : Recent-onset IDDM patients, 6 months IDDM patients, 12 months IDDM patients. B: First degree relatives, C: unrelated control subjects; $\quad p<0.03$ (Mann-Whitney U) comparing subjects $<21$ years and $\geq 21$ years of age. Statistically significant differences were not found comparing age-matched groups

insulin were highest in 21 of 35 responding subjects at $100 \mu \mathrm{g} / \mathrm{ml}(17.8 \%$ of all subjects tested). Since this concentration was in the range of concentrations used in other studies $[9,22,37,46-49]$ it was considered to be optimal.

The frequencies and magnitudes of T-cell responses to insulin were equal in age-matched IDDM patients, relatives and healthy control subjects (Fig. 2). Surprisingly, significantly higher $(p<0.03)$ and more frequent responses to insulin appeared in adult control subjects compared to young control subjects (Fig. 3), yielding a positive correlation between age and T-cell responsiveness to insulin in control subjects $\left(r_{s}=0.498, p<0.005\right)$.

Interestingly, none of the IDDM patients $(0 / 11)$ treated with insulin for 12 months displayed T-cell reactivity to insulin whereas 4 of 5 age-matched recentonset diabetic patients and 2 of 9 patients treated with insulin for 6 months did respond to insulin with T cells (Fig. 2).

IA A and T-cell response to insulin. Combining recentonset IDDM patients and all non-diabetic subjects, increased T-cell reactivity to insulin was inversely related to insulin autoantibodies $(p<0.001)$ (Fig. 4). High levels of IAA were rarely accompanied by Tcell proliferation to insulin, whereas conversely, subjects with strong T-cell proliferation were most often negative for IAA. Patients treated with insulin for at least 6 months were excluded from this analysis, since the measured IAA might not reflect true insulin autoantibodies after exogenous insulin therapy. Even amongst first degree relatives the inverse relationship of T-cell proliferation and IAA was apparent. The analysis of IAA positive and/or T-cell responding subjects showed, that in the case of IAA, the humoral response was negatively correlated with age $\left(r_{s}=\right.$ $-0.614, p<0.001)$, whereas the cellular response to insulin was positively correlated with age $\left(r_{s}=0.477\right.$, $p<0.002$ ) (Fig. 3). This demonstrates again, that age matching of the groups is essential.

T-cell response to insulin peptides. The five insulin peptides were tested at 5,15 and $50 \mu \mathrm{g} / \mathrm{ml}$. Again, the optimal concentration varied per peptide (data not shown). In the absence of a preferentially recognized concentration, all responses are plotted regardless of the concentration (Fig. 5).

Peptide recognition was similar in all groups in terms of frequency and level of responses but differed between individual peptides (Fig. 5). The B3 peptide was almost exclusively $(14 / 15)$ recognized in combination with other peptides or whole insulin, and was more frequently recognized by adult control subjects than by young control subjects $(4 / 5$ vs $1 / 11, p<0.02)$. The frequency of T-cell responders to A1, A2, B1 and $\mathrm{B} 2$ insulin peptide was similar in all groups.

At least one insulin peptide was recognized by 9 of $15(60 \%)$ recent-onset diabetic patients, 3 of $9(33 \%)$ patients treated with insulin for 6 months, 8 of 11 (73\%) patients treated with insulin for 12 months, 10 of $18(56 \%)$ first degree relatives at increased risk and 7 of $12(58 \%)$ relatives at low risk, 11 of 18 (61\%) young control subjects and 5 of $10(50 \%)$ adult control subjects (Fig. 5). Combining all subjects, 


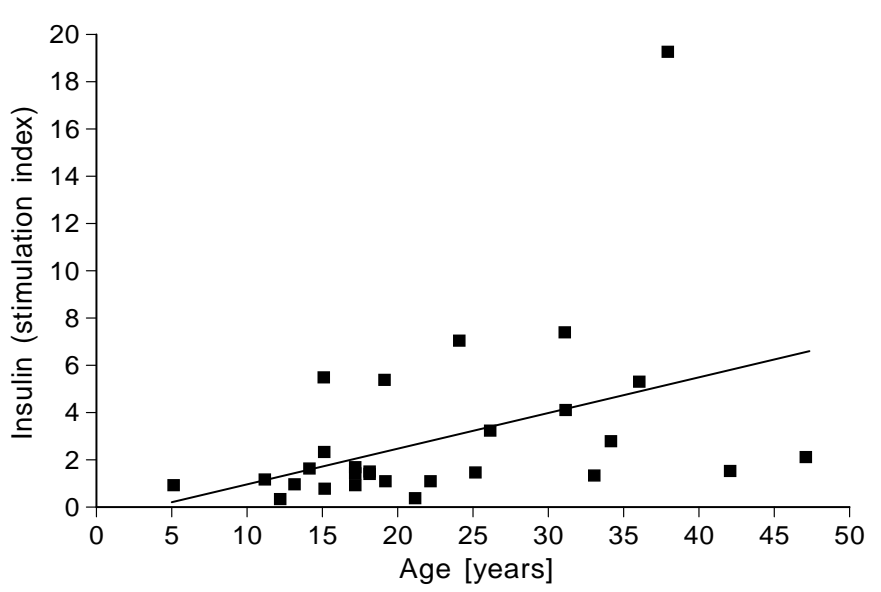

Fig. 3. Positive correlation $(p<0.005)$ of $T$-cell proliferation (stimulation index) to human insulin $(100 \mu \mathrm{g} / \mathrm{ml})$ with age in unrelated healthy control subjects

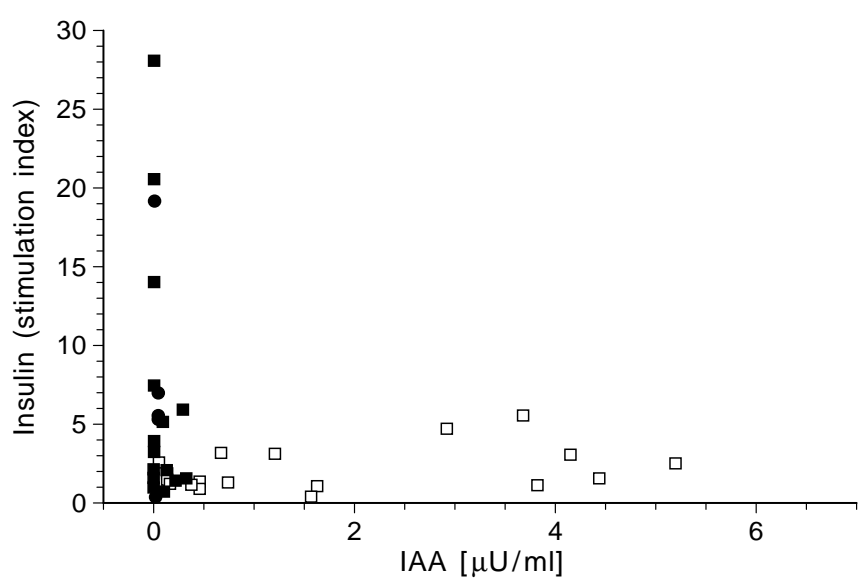

Fig. 4. Relation of B-cell response (IAA) and T-cell response (stimulation index) to insulin $(100 \mu \mathrm{g} / \mathrm{ml})$ including $\square$ recentonset IDDM patients, $\square$ first degree relatives and unrelated control subjects

53 of $96(55 \%)$ responded to at least one insulin peptide. None of the peptides tested appeared to be immunodominant or specifically recognized by patients' T cells.

Proliferative response to insulin and insulin peptides. Of all subjects tested, 18 of $96(18.8 \%)$ subjects recognized both whole insulin and insulin peptides, whereas insulin peptides alone were recognized by 35 of 96 subject $(36.5 \%)(p<0.01)$ (Fig.5). Only three subjects (two diabetic patients treated with insulin for 6 months, one unrelated adult control) recognized insulin, but none of the insulin peptides.

Recognition of the multiple peptides ('determinant spreading') was associated with recognition of the whole insulin molecule (Fig. 5). This was most evident in adult control subjects, who always recognized insulin peptides together with whole insulin $(5 / 5)$. A minority of first degree relatives at increased risk
$(2 / 11)$ or at low risk (3/7), and young control subjects (3/11) crossreacted with insulin and insulin peptides (Fig. 5). In addition, responding adult control subjects always recognized multiple peptides $(5 / 5)$, whereas young control subjects less frequently recognized multiple peptides $(7 / 11 ; 4 / 11$ reacted with one peptide). The degree of determinant spreading and insulin recognition was similar in recent-onset diabetic patients (4/9) and age-matched young control subjects (3/11). Strikingly, of the eight patients treated with insulin for 12 months and recognizing insulin peptide(s) none reacted with whole insulin $(0 / 8)$, and only responded to a single $(6 / 8)$, or two peptides $(2 / 8)$. Thus, treatment with insulin appeared to result in decreased determinant spreading compared with recent-onset patients (borderline significant $p<0.06$ ) (Fig. 5).

H L A analysis. As expected, IDDM patients and their first degree relatives more often possessed the high risk HLA-DQB1 alleles $(* 0302 / 0201)$ and less frequently the protective alleles (DQB1*0602, DQB1*0602,DQB1*0301) than healthy unrelated control subjects (Table 2 ).

T-cell reactivity to insulin or insulin peptides was not different between groups possessing high risk or protective HLA-DQB1 (Fig.5) or HLA-DQA1 (data not shown).

\section{Discussion}

In the present study we investigated T-cell and B-cell responses to insulin and insulin peptides in peripheral blood of recent-onset and insulin-treated diabetic subjects, related and unrelated healthy control subjects.

T-cell responses to insulin were detected to a similar extent in age-matched diabetic patients, young control subjects and first degree relatives at increased risk demonstrating that $\mathrm{T}$-cell reactivity to insulin (in contrast to IAA) is not necessarily indicative of IDDM. These results confirm recent studies [9, 39] but appear to be in contrast to others [16, 47-51], in which diabetic patients or individuals at risk responded more frequently and to a moderately greater extent to insulin than healthy control subjects. The different culture conditions used in distinct assays are likely to be responsible for these discrepancies. Parameters such as the incubation time of PBMCs, source of insulin as antigen, the treatment of patients with beef, pork or human insulin, and the definition of significant T-cell responses vary between published assays. Similar to our assay conditions, incubation times of 5-7 days did not reveal difference in some studies [9, 22, 39, 46, 52], but did in others [48, 49, 51].

Since T-cells and B-cells have been shown to interact during an immune response it is conceivable that B-cell responses are accompanied by simultaneous 


\begin{tabular}{|c|c|c|c|c|c|c|c|c|}
\hline Population & $\begin{array}{l}\text { No. of } \\
\text { recognized } \\
\text { peptides }\end{array}$ & $\begin{array}{l}\text { Responders/ } \\
\text { investigated } \\
\text { subjects }\end{array}$ & $\mathrm{A} 1$ & A2 & B1 & B2 & B3 & $\begin{array}{c}\text { HLA } \\
\text { DQB1 }\end{array}$ \\
\hline \multirow{9}{*}{$\begin{array}{l}\text { Recent- } \\
\text { onset } \\
\text { IDDM } \\
\text { patients }\end{array}$} & \multirow[t]{4}{*}{1} & \multirow[t]{4}{*}{$4 / 15$} & & & & & & $0302 / 0201$ \\
\hline & & & & & & & & $0501 / 0603$ \\
\hline & & & & & & & & $0603 / 0302$ \\
\hline & & & & & & & & 0201/0201 \\
\hline & \multirow[t]{3}{*}{2} & \multirow[t]{3}{*}{$3 / 15$} & & & & & & $0301 / 0201$ \\
\hline & & & & & & & & $0302 / 0201$ \\
\hline & & & & & & & & ND \\
\hline & 3 & $1 / 15$ & & & & & & ND \\
\hline & 4 & $1 / 15$ & & & & & & $0302 / 1.8$ \\
\hline \multirow{3}{*}{$\begin{array}{l}6 \text { months } \\
\text { IDDM } \\
\text { patients }\end{array}$} & 1 & $1 / 9$ & & & & & & $0201 / 0301$ \\
\hline & 2 & $1 / 9$ & & & & & & 0201/0201 \\
\hline & 3 & $1 / 9$ & & & & & & $0302 / 0201$ \\
\hline \multirow{8}{*}{$\begin{array}{l}12 \text { months } \\
\text { IDDM } \\
\text { patients }\end{array}$} & \multirow[t]{6}{*}{1} & \multirow[t]{6}{*}{$6 / 11$} & & & & & & ND \\
\hline & & & & & & & & ND \\
\hline & & & & & & & & ND \\
\hline & & & & & & & & 0501/0301 \\
\hline & & & & & & & & $0302 / 0201$ \\
\hline & & & & & & & & $0302 / 0302$ \\
\hline & \multirow[t]{2}{*}{2} & \multirow[t]{2}{*}{$2 / 11$} & & & & & & ND \\
\hline & & & & & & & & ND \\
\hline
\end{tabular}

\begin{tabular}{|c|c|c|c|c|c|c|c|c|}
\hline Group & $\begin{array}{l}\text { No. of } \\
\text { recognized } \\
\text { peptides }\end{array}$ & $\begin{array}{l}\text { Responders/ } \\
\text { investigated } \\
\text { subjects }\end{array}$ & $\mathrm{A} 1$ & A2 & B1 & B2 & B3 & $\begin{array}{c}\text { HLA } \\
\text { DQB1 }\end{array}$ \\
\hline \multirow{11}{*}{$\begin{array}{c}\text { Young } \\
\text { control } \\
\text { subjects }\end{array}$} & \multirow[t]{4}{*}{1} & \multirow[t]{4}{*}{$4 / 18$} & & & & & & 0201/0201 \\
\hline & & & & & & & & 0501/0201 \\
\hline & & & & & & & & $0502 / 0603$ \\
\hline & & & & & & & & $0602 / 0301$ \\
\hline & \multirow[t]{3}{*}{2} & \multirow[t]{3}{*}{$3 / 18$} & & & & & & ND \\
\hline & & & & & & & & $0201 / 0301$ \\
\hline & & & & & & & & 0603/0201 \\
\hline & 3 & $2 / 18$ & & & & & & $0301 / 0201$ \\
\hline & & & & & & & & $0201 / 0301$ \\
\hline & 4 & $1 / 18$ & & & & & & $0301 / 0301$ \\
\hline & 5 & $1 / 18$ & & & & & & $0602 / 0602$ \\
\hline \multirow{5}{*}{$\begin{array}{c}\text { Adult } \\
\text { control } \\
\text { subjects }\end{array}$} & \multirow[t]{2}{*}{2} & \multirow[t]{2}{*}{$2 / 10$} & & & & & & $0503 / 0601$ \\
\hline & & & & & & & & $0301 / 0401$ \\
\hline & 3 & $1 / 10$ & & & & & & $0604 / 0302$ \\
\hline & 4 & $2 / 10$ & & & & & & $0501 / 0301$ \\
\hline & & & & & & & & ND \\
\hline \multirow{7}{*}{$\begin{array}{l}\text { Relatives at } \\
\text { low risk }\end{array}$} & 1 & $1 / 12$ & & & & & & $0201 / 0201$ \\
\hline & \multirow[t]{4}{*}{2} & $4 / 12$ & & & & & & 0201/0302 \\
\hline & & & & & & & & 0201/0302 \\
\hline & & & & & & & & ND \\
\hline & & & & & & & & $0201 / 0302$ \\
\hline & \multirow[t]{2}{*}{3} & \multirow[t]{2}{*}{$2 / 12$} & & & & & & $0604 / 0201$ \\
\hline & & & & & & & & $0603 / 0201$ \\
\hline \multirow{10}{*}{$\begin{array}{l}\text { Relatives at } \\
\text { increased } \\
\text { risk }\end{array}$} & \multirow[t]{6}{*}{1} & \multirow[t]{6}{*}{$6 / 18$} & & & & & & $0301 / 0302$ \\
\hline & & & & & & & & $0302 / 0502$ \\
\hline & & & & & & & & ND \\
\hline & & & & & & & & $0302 / 0302$ \\
\hline & & & & & & & & $0302 / 0201$ \\
\hline & & & & & & & & ND \\
\hline & \multirow[t]{3}{*}{2} & \multirow[t]{3}{*}{$3 / 18$} & & & & & & 0201/0301 \\
\hline & & & & & & & & $0301 / 0603$ \\
\hline & & & & & & & & $0302(03) / 0604$ \\
\hline & 3 & $1 / 18$ & & & & & & $0201 / 0201$ \\
\hline
\end{tabular}

Fig. 5. Positive T-cell response to insulin peptides (at 5,15 or $50 \mu \mathrm{g} /$ $\mathrm{ml}$ ) simultaneously with insulin (at 15,50 or $100 \mu \mathrm{g} / \mathrm{ml}$ ) (口) or without insulin $(\square)$. Stimulation indices $\geq 3$ were considered positive. Additionally, T-cell proliferation to insulin without peptide recognition (data not shown) was observed in two IDDM patients treated with insulin for 6 months and in one healthy control subject
Table 2. Prevalence of HLA-DQB1 in the groups studied

\begin{tabular}{|c|c|c|c|c|c|}
\hline & \multicolumn{3}{|c|}{$\begin{array}{l}\text { Risk alleles } \\
\text { DQB1 *0201, *0302 }\end{array}$} & \multicolumn{2}{|c|}{$\begin{array}{l}\text { Protective alleles } \\
\text { DQB1 *0602, *0603, } \\
* 0301\end{array}$} \\
\hline Group & $\begin{array}{l}0201 / \\
0302\end{array}$ & $\begin{array}{l}0302 / x \\
\dagger\end{array}$ & $\begin{array}{l}0201 / \mathrm{x} \\
\dagger\end{array}$ & $\begin{array}{l}2 \text { protective } \\
\text { alleles }\end{array}$ & $\begin{array}{l}\text { at least } 1 \\
\text { protective } \\
\text { allele }\end{array}$ \\
\hline $\begin{array}{l}\text { IDDM } \\
\text { patients }\end{array}$ & $\begin{array}{l}11 / 35 \\
31 \%\end{array}$ & $\begin{array}{l}6 / 35 \\
17 \%\end{array}$ & $\begin{array}{l}7 / 35 \\
20 \%\end{array}$ & $\begin{array}{l}0 / 35 \\
0 \%\end{array}$ & $\begin{array}{l}11 / 35 \\
31 \%\end{array}$ \\
\hline $\begin{array}{l}\text { Relatives } \\
\text { at low risk }\end{array}$ & $\begin{array}{l}3 / 20 \\
15 \%\end{array}$ & $\begin{array}{l}4 / 20 \\
20 \%\end{array}$ & $\begin{array}{l}5 / 20 \\
25 \%\end{array}$ & $\begin{array}{l}1 / 20 \\
5 \%\end{array}$ & $\begin{array}{l}6 / 20 \\
30 \%\end{array}$ \\
\hline $\begin{array}{l}\text { Relatives } \\
\text { at high risk }\end{array}$ & $\begin{array}{l}1 / 17 \\
6 \%\end{array}$ & $\begin{array}{l}5 / 17 \\
29 \%\end{array}$ & $\begin{array}{l}7 / 17 \\
41 \%\end{array}$ & $\begin{array}{l}1 / 17 \\
6 \%\end{array}$ & $\begin{array}{l}4 / 17 \\
24 \%\end{array}$ \\
\hline $\begin{array}{l}\text { Unrelated } \\
\text { control } \\
\text { subjects }\end{array}$ & $\begin{array}{l}1 / 27 \\
4 \%\end{array}$ & $\begin{array}{l}2 / 27 \\
7 \%\end{array}$ & $\begin{array}{l}4 / 27 \\
15 \%\end{array}$ & $\begin{array}{l}6 / 27 \\
22 \%\end{array}$ & $\begin{array}{l}22 / 27 \\
81 \%\end{array}$ \\
\hline
\end{tabular}

$\dagger$, Not DQB1 *0102/*0301, x; not DQB1 *0602,*0603,*0301

T-cell responses to a given antigen. However, in our study diabetic subjects were in most cases IAA positive and T-cell proliferation was low or negative, whereas non-diabetic control subjects and relatives displayed T-cell responses but not antibodies to insulin. Even amongst first degree relatives an inverse relation of IAA and T-cell response was apparent. Similarly, an inverse correlation of autoantibodies and Tcells to an islet autoantigen was previously observed in the case of GAD67 [53] where T-cell responses to GAD67 were associated with the development to diabetes in three of four ICA positive subjects. In another study, the inverse relation of T-cell reactivity and antibodies to the islet autoantigen ICA69 was shown to be HLA dependent [54]. Our data, with diabetic subjects positive for IAA and healthy subjects who responded with autoimmune T-cells imply that insulin-specific $\mathrm{T}$-cell reactivity does not correlate with autoimmune disease and therefore cannot be used as a predictive marker for IDDM. In addition, no relation of T-cell responses to insulin with HLA was detected in our study, which is not surprising due to the lack of statistical power given by the low numbers of responding subjects. Nevertheless, we detected a positive correlation of T-cell responsiveness with age. In light of the reciprocal association of antibodies [55-58] and $\mathrm{T}$ cells with age, the need for matching of age of the control group with the patient and high risk subjects is evident.

We furthermore analysed the T-cell response to insulin peptides which were significantly more often recognized in the absence of insulin than in combination with insulin $(36.5$ vs $18.8 \%, p<0.01)$. However, no disease specific or immunodominant epitopes were identified in contrast to studies in NOD mice, where the B2 peptide was preferably recognized and $T$ cells from NOD mice specific for the immunodominant insulin peptide A2 or B2 (both peptides are identical in murine and human insulin) were shown 
to be diabetogenic [59]. The recognition of multiple insulin peptides in our study was increasingly accompanied by recognition of the whole insulin molecule. It has been hypothesized that one or more immunodominant determinants may be responsible for autoimmune disease in the early stage, and that subsequently, intra- and intermolecular spreading of epitopes occurs, leading to a diverse repertoire and increased determinant spreading in the late stage of disease $[31,60,61]$. However, the degree of determinant spreading in relatives at high risk, recent-onset diabetic subjects and healthy age-matched control subjects was similar. Remarkably, adult control subjects differed from young control subjects in that they recognized insulin peptides exclusively in combination with whole insulin, whereas only few young control subjects recognized both insulin and insulin peptides. This again illustrates the importance of appropriate age matching of control groups with patients. In humans, the lack of recognition of a disease specific or immunodominant insulin epitope together with the appearance of autoreactive T cells in healthy as well as diabetic individuals demonstrate, that insulin reactive $\mathrm{T}$ cells are not necessarily indicative of autoimmune diabetes. This notion is in accordance with other autoimmune diseases such as autoimmune thyroiditis or multiple sclerosis, in which autoreactive $\mathrm{T}$ cells are also detectable in both patients and control subjects $[62,63]$.

It has been shown that exogenous insulin can modulate immune responses in animals and humans [28$30,34,35,59]$ leading to a delay or even prevention of autoimmune diabetes. Interestingly, insulin-treated IDDM patients differed from newly diagnosed patients, relatives at risk and unrelated control subjects in several aspects. First, simultaneous immune recognition of insulin with T cells and IAA was only seen in patients treated for 6 months with insulin. Second, T cells of insulin-treated patients rarely recognized the whole insulin molecule. Third, insulintreated patients displayed less determinant spreading, and fourth, recognition of multiple peptides was not accompanied by crossreactivity to the whole insulin molecule. Together, these observations suggest that exogenous insulin administration reduces T-cell reactivity to insulin and insulin peptides. To prove these observations, longitudinal studies have to be performed investigating IDDM patients at disease onset and during the course of insulin therapy.

Our results describe an altered immune response to insulin in adult and young subjects, and suggest a decreased recognition of insulin and insulin peptides in patients treated with insulin which may partly explain the beneficial effect of insulin administration observed in the pilot trial. This implies the activation of different T-cell subsets in patients and control subjects. Whether insulin therapy prior to onset of diabetes can induce the development of non-destructive, or even protective T-cell subsets must be analysed in further studies, including those subjects from the Diabetes Prevention Trial who are treated with insulin before they develop overt diabetes.

A cknowledgements. This work was supported by Research Grants from the National Institute of Health grants GK 32083 (to G.E.), RO1 DK 46621 and RO1 DK 47298 (to D.W.). B.R. is a fellow of the National Academy of Arts, the Netherlands.

\section{References}

1. Eisenbarth GS (1986) Type I diabetes mellitus. A chronic autoimmune disease. N Engl J Med 314: 1360-1368

2. Atkinson MA, Maclaren NK (1994) The pathogenesis of insulin-dependent diabetes mellitus. N Engl J Med 331: 1428-1436

3. Palmer JP, Asplin CM, Clemons P et al. (1983) Insulin antibodies in insulin-dependent diabetes before insulin treatment. Science 222: 1337-1339

4. Riley WJ, Atkinson MA, Maclaren NK (1988) Insulin autoantibodies in pre-diabetes. Adv Exp Med Biol 246: 45-51

5. Bottazzo GF, Florin-Christensen A, Doniach D (1974) Islet cell antibodies in diabetes mellitus with autoimmune polyendocrine deficiencies. Lancet ii:1279-1282

6. Payton MA, Hawkes CJ, Christie MR (1995) Relationship of the 37,000- and 40,000- $\mathrm{M}_{\mathrm{r}}$ tryptic fragment of islet antigens in insulin-dependent diabetes to the protein tyrosine phosphatase-like molecule IA-2 (ICA512). J Clin Invest 96: 1506-1511

7. Christie MR, Genovese S, Cassidy D et al.(1994) Antibodies to islet $37 \mathrm{k}$ antigen, but not to glutamate decarboxylase, discriminate rapid progression to IDDM in endocrine autoimmunity. Diabetes 43: 1254-1259

8. Gianani R, Rabin DU, Verge CF et al. (1995) ICA512 Autoantibody Radioassay. Diabetes 44: 1340-1344

9. Durinovic-Bello I, Hummel M, Ziegler AG (1996) Cellular immune response to diverse islet cell antigens in IDDM. Diabetes 45: 795-800

10. Atkinson MA, Maclaren NK, Scharp DW, Lacy PE, Riley WJ (1990) 64,000 $\mathrm{M}_{\mathrm{r}}$ autoantibodies as predictors of insulin-dependent diabetes. Lancet 335: 1357-1360

11. Christie M, Landin-Olsson M, Sundkvist G, Dahlquist G, Lernmark A, Baekkeskov S (1988) Antibodies to a $\mathrm{M}_{\mathrm{r}^{-}}$ 64,000 islet cell protein in Swedish children with newly diagnosed type 1 (insulin-dependent) diabetes mellitus. Diabetologia 31: 597-602

12. Gerling I, Baekkeskov S, Lernmark A (1986) Islet cell and $64 \mathrm{~K}$ autoantibodies are associated with plasma IgG in newly diagnosed insulin-dependent diabetic children. J Immunol 137: 3782-3785

13. Foulis AK, McGill M, Farquharson MA (1991) Insulitis in type-1 (insulin-dependent) diabetes-mellitus in man - macrophages, lymphocytes, and interferon-gamma containing cells. J Pathol 165: 97-103

14. Sibley R, Sutherland DER, Goetz F, Michael AF (1985) Recurrent diabetes mellitus in the pancreas iso- and allograft. A light and electron microscopic and immunohistochemical analysis of four cases. Lab Invest 53: 132-144

15. Lampeter EF, Homberg M, Quabeck K et al. (1993) Transfer of insulin-dependent diabetes between HLA-identical 
siblings by bone marrow transplantation. Lancet 341: 12431244

16. Naquet P, Ellis J, Tibensky D et al. (1988) T cell autoreactivity to insulin in diabetic and related non-diabetic individuals. J Immunol 140: 2569-2578

17. Roep BO, Arden SD, De Vries RRP, Hutton JC (1990) Tcell clones from a type-1 diabetes patient respond to insulin secretory granule proteins. Nature 345: 632-634

18. Roep BO, Kallan AA, Hazenbos WL et al. (1991) T-cell reactivity to $38 \mathrm{kD}$ insulin-secretory-granule protein in patients with recent-onset type 1 diabetes. Lancet 337: 14391441

19. Atkinson MA, Kaufman DL, Campbell L et al. (1992) Response of peripheral-blood mononuclear cells to glutamate decarboxylase in insulin-dependent diabetes. Lancet 339: 458-459

20. Honeyman MC, Cram DS, Harrison LC (1993) Glutamic acid decarboxylase 67-reactive T cells: a marker of insulindependent diabetes. J Exp Med 177: 535-540

21. Harrison LC, De Aizpurua H, Loudovaris T et al. (1991) Reactivity to human islets and fetal pig proislets by peripheral blood mononuclear cells from subjects with preclinical and clinical insulin-dependent diabetes. Diabetes 40: 11281133

22. Keller RJ (1990) Cellular immunity to human insulin in individuals at high risk for the development of type I diabetes mellitus. J Autoimmun 3: 321-327

23. Haskins K, Portas M, Bradley B, Wegmann D, Lafferty K (1988) T-lymphocyte clone specific for pancreatic islet antigen. Diabetes 37: 1444-1448

24. Bergman B, Haskins K (1994) Islet-specific T-cell clones from the NOD mouse respond to beta-granule antigen. Diabetes 43: 197-203

25. Schloot N, Gottlieb P, Wegmann D (1996) Characterization of diabetogenic, GAD65-specific T cell clones established from NOD mice. Diabetes 45:A307 (Abstract)

26. Wegmann DR, Shehadeh N, Lafferty KJ, Norbury-Glaser M, Gill RG, Daniel D (1993) Establishment of islet-specific T-cell lines and clones from islet isografts placed in spontaneously diabetic NOD mice. J Autoimmun 6: 517-527

27. Daniel D, Gill RG, Schloot N, Wegmann D (1995) Epitope specificity, cytokine production profile and diabetogenic activity of insulin-specific $\mathrm{T}$ cell clones insolated from NOD mice. Europ J Imm 25: 1056-1062

28. Zhang JZ, Davidson I, Eisenbarth G, Weiner HL (1991) Suppression of diabetes in nonobese diabetic mice by oral administration of porcine insulin. Proc. Natl Acad Sci USA 88: 10252-10256

29. Atkinson MA, Maclaren NK, Luchetta R (1990) Insulitis and diabetes in NOD mice reduced by prophylactic insulin therapy. Diabetes 39: 933-937

30. Daniel D, Wegmann DR (1996) Protection of nonobese diabetic mice from diabetes by intranasal or subcutaneous administration of insulin peptide b-(9-23). Proc Natl Acad Sci U S A 93: 956-960

31. Kaufman DL, Clare-Salzler MJ, Tian JD et al. (1993) Spontaneous loss of T-cell tolerance to glutamic acid decarboxylase in murine insulin-dependent diabetes. Nature 366: 6972

32. Tisch R, Yang XD, Singer SM, Liblau RS, Fugger L, McDevitt HO (1993) Immune response to glutamic acid decarboxylase correlates with insulitis in non-obese diabetic mice. Nature 366: 72-75

33. Tian J, Atkinson MA, Clare-Salzler M et al. (1996) Nasal administration of glutamate decarboxylase (GAD65) peptides induces Th2 responses and prevents murine insulin-dependent diabetes. J Exp Med 183: 1561-1567
34. Keller RJ, Eisenbarth GS, Jackson RA (1993) Insulin prophylaxis in individuals at high risk of type I diabetes [see comments]. Lancet 341: 927-928

35. Schloot N, Eisenbarth GS (1995) Isohormonal therapy of endocrine autoimmunity. Immunology Today 16: 289-294

36. Song Y-H, Li Y, Maclaren NM (1996) The nature of autoantigens targeted in autoimmune endocrine diseases. Immunology Today 17: 232-238

37. Miller GG, Pollack MS, Nell LJ, Thomas JW (1987) Insulinspecific human T cells. J Immunol 139: 3622-3629

38. Ito Y, Nieda M, Uchigata Y et al.(1993) Recognition of human insulin in the context of HLA-DRB $1 * 0406$ products by T-cells of insulin autoimmune syndrome patients and healthy donors. J Immunol 151: 5770-5776

39. Atkinson M, Leslie D (1994) Inverse relation between humoral and cellular immunity to glutamic acid decarboxylase in subjects at risk of insulin-dependent diabetes Comment. J Endocrinol Invest 17: 581-584

40. Bingley PJ, Christie MR, Bonifacio E et al. (1994) Combined analysis of autoantibodies improves prediction of IDDM in islet cell antibody-positive relatives. Diabetes 43: $1304-1310$

41. Yu L, Chase HP, Falorni A, Rewers M, Lernmark A, Eisenbarth GS (1995) Sexual dimorphism in transmission of expression of islet autoantibodies to offspring. Diabetologia 38: $1353-1357$

42. Bugawan TL, Erlich HA (1991) Rapid typing of HLADQB1 DNA polymorphism using nonradioactive oligonacleotide probes and amplified DNA. Immunogenetics 33: 163-170

43. Nell LJ, Virta VJ, Thomas JW (1985) Recognition of human insulin in vitro by $\mathrm{T}$ cells from subjects treated with animal insulins. J Clin Invest 76: 2070-2077

44. Roep BO, Kallan AA, Duinkerken G et al. (1995) T-cell reactivity to beta-cell membrane antigens associated with beta-cell destruction in IDDM. Diabetes 44: 278-283

45. Schloot NC, Roep BO, Wegmann DR, Yu L, Wang T, Eisenbarth GS (1997) T-cell reactivity of GAD65 peptide sequences shared with coxsackie virus protein in recent onset IDDM, post onset IDDM patients and control subjects. Diabetologia 40: 332-338

46. Nell LJ, Thomas JW (1983) The human immune response to insulin. J Immunol 131: 701-705

47. Scheinin T, Maenpaa J, Kontiainen S (1990) Immune responses to insulin and lymphocyte subclasses at diagnosis of insulin-dependent diabetes and one year later. Immunobiology 180: 431-440

48. Gregory R, Tattersall RB (1993) Bovine and human NPH insulin as $\mathrm{T}$ cell immunogens. Diab Res Clin Pract 20: 139-146

49. MacCuish AC, Jordan J, Campbell CJ, Duncan LPJ, Irvine WJ (1975) Cell mediated immunity in diabetes mellitus: lymphocyte transformation by insulin and insulin fragments in insulin treated and newly diagnosed diabetics. Diabetes 24: 36-43

50. Scheinin T, Maenpaa J, Koskimies S, Dean BM, Bottazzo GF, Kontiainen S (1988) Insulin responses and lymphocyte subclasses in children with newly diagnosed insulin-dependent diabetes. Clin Exp Immunol 71: 91-95

51. Atkinson MA, Bowman MA, Kao KJ et al. (1993) Lack of immune responsiveness to bovine serum albumin in insulin-dependent diabetes. N Engl J Med 329: 1853-1858

52. Atkinson MA, Bowman MA, Campbell L, Darrow BL, Kaufman DL, Maclaren NK (1994) Cellular immunity to a determinant common to glutamate decarboxylase and coxsackie virus in insulin-dependent diabetes. J Clin Invest 94: 2125-2129 
53. Harrison LC, Honeyman MC, De Aizpurua HJ et al. (1993) Inverse relation between humoral and cellular immunity to glutamic acid decarboxylase in subjects at risk of insulindependent diabetes. Lancet 341: 1365-1369

54. Roep BO, Duinkerken G, Schreuder GM, Kolb H, de Vries RR, Martin S (1996) HLA-associated inverse correlation between $\mathrm{T}$ cell and antibody responsiveness to islet autoantigen in recent-onset insulin-dependent diabetes mellitus. Eur J Immunol 26: 1285-1289

55. McEvoy RC, Witt ME, Ginsberg-Fellner F, Rubinstein P (1986) Anti-insulin antibodies in children with type I diabetes mellitus. Genetic regulation of production and presence at diagnosis before insulin replacement. Diabetes 35: 634641

56. Arslanian SA, Becker DJ, Ralrin B (1985) Correlates of insulin antibodies in newly diagnosed children with insulindependent diabetes before insulin therapy. Diabetes 34: 926-930

57. Levymarchal C, Czernichow P (1993) Heterogeneity of type-1 diabetes at onset in children - results from the French incidence study. Diabete Metab 19: 296-303

58. Verge CF, Howard NJ, Rowley MJ et al. (1994) Anti-glutamate decarboxylase and other antibodies at the onset of childhood IDDM: a population-based study. Diabetologia 37: $1113-1120$

59. Daniel D, Wegmann D (1996) Protection of nonobese diabetic mice from diabetes by intranasal or subcutaneous administration of insulin peptide B-(9-23). Proc Natl Acad Sci USA 93: 956-960

60. Lehmann PV, Sercarz EE, Forsthuber T, Dayan CM, Gammon G (1993) Determinant spreading and the dynamics of the autoimmune T-cell repertoire. Immunol Today 14: 203-208

61. Yu M, Johnson JM, Tuohy VK (1996) A predictable determinant spreading cascade invariably accompanies progression of experimental autoimmune encephalomyelitis: a basis for peptide-specific therapy after onset of clinical disease. J Exp Med 183: 1777-1788

62. Fisfalen M, Soliman M, Okamoto Y, Solitani K, DeGroot LJ (1995) Proliferative responses of T-cells to thyroid antigens and synthetic thyroid peroxidase peptides in autoimmune thyroid disease. J Clin Endocrinol Metab 80: $1597-$ 1604

63. van Noort JM, Sechel AC, Bajramovic JJ et al. (1995) The small heat-shock protein alpha $\beta$-crystallin as candidate autoantigen in multiple sclerosis. Nature 375: 798-801 